\title{
MARITIME TOURISM: GLOBAL SUCCESS STORIES AND THE CASE OF PAKISTAN
}

\author{
Naureen Fatima ${ }^{1}$ \\ Muhammad Akhtar ${ }^{2}$
}

\begin{abstract}
The coastal / maritime tourism is an important segment in a multi-trillion dollars and multivariate global tourism industry. It offers one of the new avenues and fastest growing areas for significant role in global economies. Various countries such as Maldives, Indian State of Kerala, Singapore and Thailand etc. have focused on maritime tourism with good governance practices evolved over period of time to earn substantial revenues from it. Pakistan has also immense maritime tourism potential with diversified natural, religious, and cultural tourism resources. But Pakistan's maritime tourism is considered very weak due to various issues. With qualitative research, this paper attempts to explore and suggest solutions for the development of maritime tourism sector of Pakistan by analysing the tourism governance of global success stories and evaluating the nationwide potential and challenges. Arguments are developed that the factors behind the success stories of Maldives \& Kerala state in India can act as guidance for taking initiatives on the proposed potential sites in order to uplift the maritime tourism sector in Pakistan. It is anticipated that the effective implementation of this paper's recommendations would be instrumental in gearing up Pakistan's Maritime economy.
\end{abstract}

Keywords: Coastal, Maritime, Maldives, Kerala, Tourism governance, Success stories, Potential sites

Naureen Fatima is a Researcher- Maritime Tourism \& Coastal Livelihoods at National Institute of Maritime Affairs (NIMA) reachable at naureen.naveed27@gmail.com

Muhammad Akhtar is Deputy Director at NCMPR Karachi reachable at dd.ncmpr@bahria.edu.pk 


\section{Introduction}

In this modern era, tourism has now grown to a multi-trillion dollars and multivariate trade activity across the globe. The International Year of Tourism 2017 has acknowledged the significance of this sector to a country's economic activities and employment generation worldwide. Around 1,323 million international tourists' arrivals were reported at different destinations across the globe during the year 2017 (UNWTO, 2017) ${ }^{3}$. But in Pakistan, the tourism sector seems to be dismal despite having diversified natural, historical, and cultural attractions in place. Travel and Tourism Competitiveness Index report ranked Pakistan to $122^{\text {nd }}$ number out of 140 nations ${ }^{4}$. Last 6 years data from Office of Integrated Border Management System (IBMS) of Federal Investigation Agency (FIA) in Islamabad has revealed very surprising facts about foreign visitors who visited Pakistan on tourist visa. According to which, 10,560, 5,575, 6,475, 9161, 10,476 and 17,823 foreign tourists have been reported in years 2013, 2014, 2015, 2016, 2017 and 2018, respectively. According to Baloch $(2007)^{5}$, the annual foreign tourist arrival in Pakistan was observed less than its regional countries i.e., Maldives, India, and Iran during the year 2007. The 42 million domestic tourists travelled in the country in the year $2005^{6}$. Out of which, almost $90 \%$ of tourists travelled by road, $8.5 \%$ by railways and only $1.8 \%$ travelled by airways 7 .It is quite alarming that the previous tourism related research papers, articles and other

3 UNWTO Annual Report 2017, accessed on July, 9, 2012, https://www.eunwto.org/doi/book/10.18111/9789284419807

${ }^{4}$ Rana Ejaz Ali Khan, and Muhammad Kamran Rasheed, "Political economy of tourism in Pakistan: The role of terrorism and infrastructure development,"

Asian Development Policy Review, 4, no. 2, (2016): 47-50.

${ }^{5}$ Qadar Baksh Baloch, "Managing tourism in Pakistan: A case study of Chitral valley," Journal of Managerial Sciences, 2, no.2, (2017): 169-190.

6 Baloch, "Managing tourism in Pakistan", 176.

7 Samina Khalil, Mehmood Khan Kakkar, and Waliullah, "Role of tourism in economic growth: empirical evidence from Pakistan economy," Pakistan Development Review, 46, no. 4, (2007): 985-995. 
reports have issues of authentic data. However, according to the World Travel \& Tourism Council, Pakistan's tourism contributed approximately $3.1 \%$ in the GDP in year 2013 which was subsequently observed higher by World Data Atlas in year 2017 i.e., 7.4\%. Currently, Pakistan is ranked on a very low number i.e. 125 in terms of World Tourism Income. ${ }^{8}$

It is pertinent to mention that the coastal / maritime tourism is an important segment of global tourism industry. It has now become one of the new avenues and fastest growing areas for significant role in global economies. Various countries such as Maldives, Singapore, Thailand, and State of Kerala in India etc. have focused agenda on maritime tourism and have evolved good governance practices thus generating substantial revenues from it. The role of maritime tourism is well integrated into contemporary economies that the economic impact is relevant even to the less important countries in terms of tourism-related activities. The experiences of Pakistan's neighbouring countries show sustainable revenue generation from maritime tourism which is quite attractive not only for the domestic but also for the foreign tourists. Kerala's tourism industry earns over US $\$ 5$ billion per annum (Kerala Tourism Statistics, 2017) ${ }^{9}$ and Maldives's economy primarily relies on maritime tourism with approximate $28.78 \%$ of its contribution towards national GDP ${ }^{10}$.

Pakistan has also immense maritime tourism potential with more than $1000 \mathrm{~km}$ long coastline, which is blessed with

8 World Travel \& Tourism Council Report, (2018), https://www.wttc.org/Lmedia/files/reports/economic-impact-research/archived/countries2018/pakistan2018.pdf.

${ }^{9}$ Kerala Tourism Statics, (2017), accessed on April 24, 2019, https://www.keralatourism.org/tourismstatistics/tourist statistics_2017201803141 22614.pdf.

${ }^{10}$ It is based on reported tourism figures during the implementation phase of Third Tourism Master Plan, Quoted in Malives Economy by Global Edge, Michigan State University, (2007-2011), accessed on August, 20, 2019, https://globaledge.msu.edu/countries/maldives/economy. 
diversified natural, religious, and cultural tourism resources ${ }^{11}$. The Government of Pakistan upgraded the tourism sector to the separate industry status in 1989. Under Pakistan National Tourism Policy (1990), the Federal Government was advised to establish a Beach Development Authority for the development of beaches and to provide incentives on the equipment for water sports activities. The National Maritime Policy (NMP-2002) has also underlined the importance of maritime tourism as it proposed to the Ministry of Sports, Culture, Tourism \& Youth Affairs, with the collaboration of Sindh and Balochistan provinces to devise a long-term effective policy for promotion of maritime tourism and water sports activities. However, despite all these measures, the case of Pakistan's maritime tourism is considered weak due to uncertain influences such as political instability, lack of coordination among tourism departments and security issues over the last two decades. ${ }^{12}$

In the context above, this paper aims to explore and suggest solutions for the development of maritime tourism sector of Pakistan by analysing and showcasing the tourism governance of global success stories and evaluating the nationwide potential and challenges.

\section{Methodology}

This paper employs qualitative research methodology and has scrutinized the relevant primary and secondary sources of data/ information with two case studies of global tourism success stories i.e. Tourism in Maldives and Kerala. Thematic and content analysis was done for the Tourism Master Plans of -Maldives since

11 Ziaullah, Jehangir Khan, and Zahoor Ul Haq, "Coastal Tourism \& CPEC: Opportunities and Challenges in Pakistan", Journal of Political Studies, 25, no. 2, (2018): 261-272.

Zia Ullah, Prof. David Johnson, Prof. Allan T. Williams, Dr Anthony Gallagher, and Muhammad Qasim, "Strategic Analysis of Coastal Tourism in Pakistan (A Case Study of Sindh Province). Journal of Applied Environmental and Biological Sciences, 4(7S), (2014): 107-112.

12 Razzaq Ahmed, and Khalida Mahmood, "Tourism potential and constraints: An analysis of tourist spatial attributes in Pakistan", Pakistan Perspectives, 22, no.2, (2017). 
1983 to 2017, Maldives Tourism Act ${ }^{13}$, Kerala Tourism Policy 201214, Kerala Tourism Statistics 2017, Pakistan's National Tourism Policy 1990 and Pakistan's National Maritime Policy 2002. A one-day stakeholders' consultative workshop was organized on 4th April 2019 at Karachi, where key issues, challenges and solutions for maritime tourism in Pakistan were discussed, debated and concluded by the most relevant actors of tourism sector. Subsequently, the findings of the workshop were refined by sharing in a Maritime Tourism Panel Discussion that was organized during Pakistan Tourism Dialogue (PTD) event held on 18 April 2019 at Pak-China Friend ship Centre, Islamabad. A Key Informant Interview of Deputy Head Mission / First Secretary Maldives in Pakistan was carried out on 23rd May 2019 to validate the governance mechanism of Maldives tourism. Chronological Matrix was developed for the overall evaluation of Maldives tourism development and evolution of its governance mechanism over period of time. Graphs were developed by using Microsoft Excel 2013 to show tourist flux and earnings in Kerala and Maldives. A range of relevant previous analysis and opinions generated by experts, relevant national/ international documents, and academicians in peer reviewed publications were taken into account by expert analysis technique through an in-house session to deduce findings and conclusion, and to generate recommendations for practical actions including governance measures proposed for Pakistan's maritime tourism.

\section{Global Success Stories of Tourism Development}

In the recent era, the global tourism market has reached to exponential growth and its diversification is making it one of the fastest growing economic sectors. The international tourist arrivals have grown continually from 25 million in the year 1950 to a total of 1.186 billion arrivals in 2015. This exponential growth has further projected to rise further. According to UNWTO forecast, the international tourist arrival will reach 1.8 billion by the end of 2030. A large number of countries comprising of Maldives, Sri

\footnotetext{
13 Maldives Tourism Act (Law No. 2/99), Government of Maldives 14 Kerala Tourism Policy, 2012, Government of Kerala, India.
} 
Lanka, State of Kerala in India, Queensland state in Australia etc. had devised strategic tourism policies and plans and succee ded in this very important sector of the economy ${ }^{15}$. Following are the tourism policy reviews of some successful countries/provinces that succeeded and got benefitted from the maritime touris $m$ sector of tourism

industry

\section{Review of Kerala Tourism Policy Success:}

The Kerala Tourism Policy was periodically revised in 2012 and then in 2017 to promote responsible and sustainable tourism in Kerala State, India. Policy version of the year 2012 primarily focused on harnessing the unique products of Kerala such as Backwater Tourism \& Ayurveda with the emerging innovations of sustainable development and was quite successful in attaining international appreciation. The rationales behind the revision of Policy in 2012 were the growing trends in foreign/domestic tourist arrivals, foreign exchange, and total earnings, which were significant due to taking good initiatives such as introduction of tourism development programme in 1976, declaring tourism as an industry in 1986 and realizing the importance of public-private partnership vide first policy document in 1995 by the Government of Kerala. Tourism statistics of the years 2001 and 2010 showed that the number of foreign tourist arrivals in Kerala increased to more than thrice i.e. from 208,830 to 659,265 ; the number of local tourist arrivals increased to about $64 \%$ i.e. from 5,239,692 to $8,595,075$; foreign exchange earnings were increased more than 7 times i.e. from Indian Rs.5.35 billion to Rs.37.97 billion, and total earnings of Kerala quadrupled, from Indian Rs. 45 billion to Rs.173.48 billion. These statistical figures clearly indicate the success of the first Tourism Policy of 1995. The revised Policy version 2012 reflects the inclusion of lessons learned, specialized incentives, visionary measures and commitment to increase further the dominating factors of Kerala Tourism products. That is why, tourism statistics for the year 2017 depicts further remarkable increase as compared with the previous state of affairs

15 Dirk Glaesser, John Kester, Hanna Paulose, Abbas Alizadeh, and Birka Valentin,

“Global travel patterns: An overview," Journal of travel medicine, 24, no.4, (2017). 
for the year 2010. By the year 2017, the number of foreign tourist arrivals in Kerala increased to more than thrice i.e., from 659,265 to $1,091,870$; the number of local tourist arrivals increased to about $70 \%$ i.e. from $8,595,075$ to $14,673,520$; foreign exchange earnings increased more than 2 times i.e. from Indian Rs.37.97 billion to Indian Rs.83.92 billion; and total earnings of Kerala got 92.4\% incremental effect i.e. from Indian Rs. 173.48 billion to Indian Rs.333.83 billion. Figure 1 shows revenue trends that is the total earnings from tourism sector in Kerala, while figure 2 show s foreign and domestic tourist arrivals in Kerala State during the years 2001, 2010 and 2017.

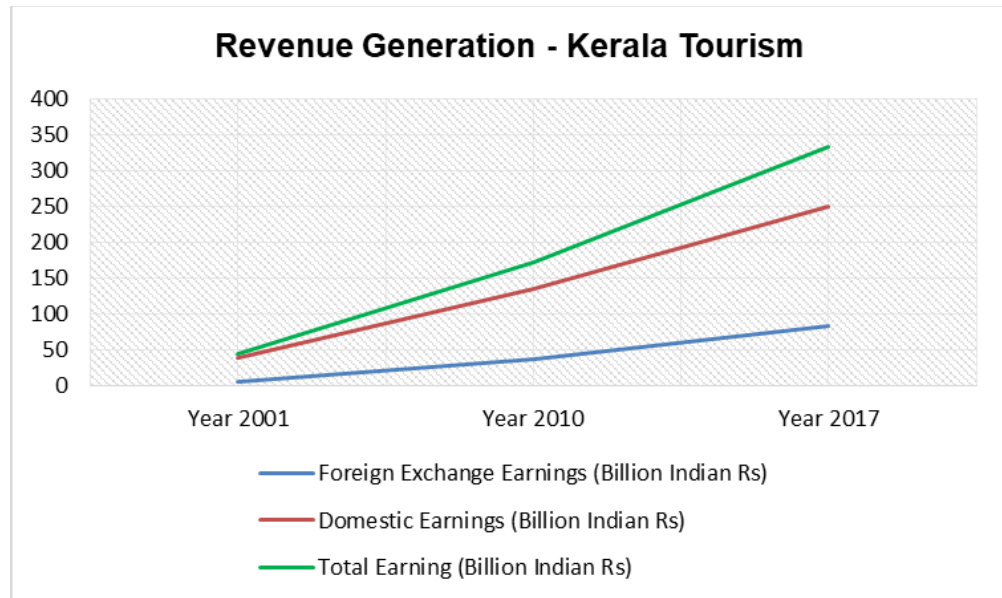

Figure 1: Revenue Trends in Kerala Tourism - 2001 to 2017. (Source: Kerala Statistics 2017)

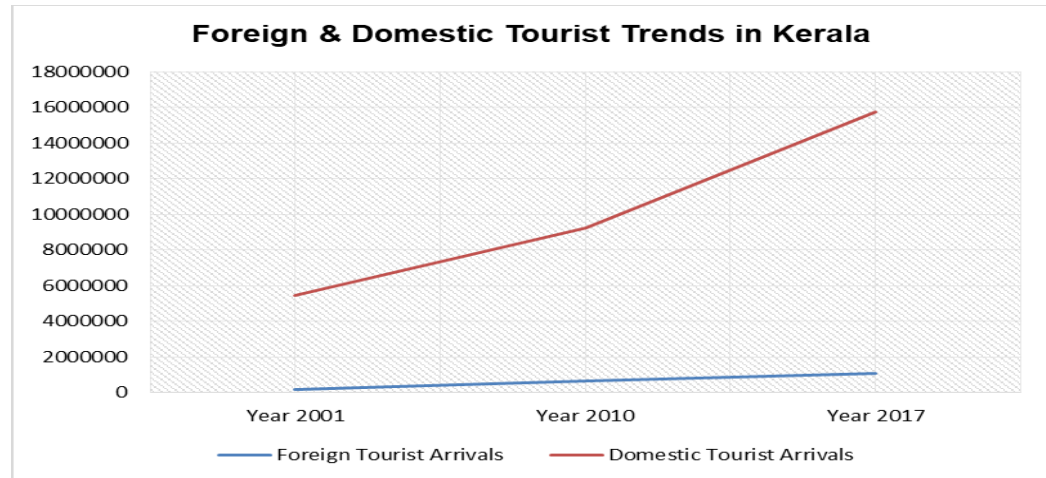

Figure 2: Trends of Tourist Arrivals in Kerala - 2001 to 2017. (Source: Kerala Statistics 2017) 
In this modern era of the consumer economy, Kerala Tourism Policy 2012 recognizes the importance of the level of satisfaction of visitors. Thus, its basic thrust was on infrastructure with four major precursors i.e., water supply system, road accessibility, streetlights, and proper waste-management system. Besides, some necessary auxiliary components such as wayside facilities including toilets and rest areas, Hop-on Hop-off services, parking bays, jetties, and boarding points were also taken into account. Development of 10 thematic museums to showcase the cultural heritage of Kerala is also an important policy step for value addition in existing tourism products.

For an effective and vibrant governance mechanism through overseeing, executing and monitoring the tourism affairs; the policy 2012 also introduced a tourism Cabinet Committee on Tourism chaired by the Chief Minister, a Task Force for Kerala Waste Free Destination (KWFD) campaign chaired by Minister of Tourism, fast track clearance mechanisms for tourism projects, banned plastic use at major tourist destinations, coordinated efforts with Kerala State Pollution Control Board, a new subsidy system and a Task Force to foster responsible tourism practices, a Task Force against Trafficking and Child Abuse, a Contingency Response Cell to tackle the emergency situation, a Life-Saving Volunteer scheme, Tourist Warden Scheme by employing local educated manpower particularly women cadre, Entrepre neurship Development Programme to enable Local Level Entrepreneurs (LLE) for the promotion of community-based tourism, system of exclusive tourist profile to strengthen market research, marketing strategies including the applications of social marketing tools and a systematic periodic review system and grading system by employing a feedback survey mechanism at major tourist destinations in Kerala State in order to ensure the quality of their tourism products. 


\section{Maldives Tourism - A Success Story of Good Maritime Governance}

The tourism industry in Maldives took off in the early 1970s, initially linked with the myth that no substantial tourism can be developed due to its geographical location and hardships towards basic facilities. In 1960, it was believed by the United Nations that the Maldives was not a suitable destination for tourism ${ }^{16}$. Today, the United Nations theory has been proven wrong as the success story of Maldives' global tourism was achieved through its national determination, strategic planning and its effective execution alongwith good governance norms and product-based approach evolving from its 1st Master Plan (1983-1992) to 4th Master Plan (20132017). First two Tourism Master Plans were developed on a 10year span basis. However, the duration of succeeding plans was reduced to five-year period due to the reasons of the overwhelming success of first two master plans, major tsunami incident in the year 2004 and effective management review for continual improvement by strengthening the grey areas through planning and best practices.

In 1972, tourism started with only two island resorts having capacity of 280 beds. By the end of the 1970s and middle of 1980s, the increasing interest of Europe's international tourists made this important sector an important income source for the Maldives. Approximately $64 \%$ of tourists come to the Maldives for relaxation, approximate $20 \%$ for Honeymoon purpose and rest for other purposes including water sports, and entertainment. So far, key tourism products developed include snorkelling, scuba diving, jet skiing, night fishing, sailing, windsurfing, kayaking, Kitesurfing, one island: one hotel, spa, cruising, underwater restaurants etc. Comparing other islands of its size, the growth of Maldives tourism trajectory shows a great success story in the whole region.

After the expansion of infrastructure facilities and effective execution of the Maldives Tourism Plans, the tourist arrivals grew to an unbelievable number of $1,389,542$ by the end of 2017

\footnotetext{
${ }^{16}$ Suresh Kumar Kundur, "Development of Tourism in Maldives," Journal of Scientific and Research Publications, 2. No. 4, (2012), 1.
} 
compared to the starting point of 1097 arrivals in 1972 and Fourth Tourism Master Plan (4TMP) aspires to further rise to 2.5 million in 2021. During 2002-2017, the tourism sector contributed an average of $27.5 \%$ towards Maldives's GDP (minimum $22.7 \%$ in the year 2005 and a maximum of $32.7 \%$ in the year 2003) ${ }^{17}$. The tourist accommodation has also (resorts, marinas, hotels, safari-boats, etc.) increased to 41,255 beds by the end of 2017 . The Maldives has a unique feature of a high degree of repeat visitation. Sustainable tourism development has been considered the key to success of Maldives as a favourite tourist destination in the region. Therefore, the World Tourism Organization (WTO) has marked the Maldives a model for sustainable tourism development. Figure 3 shows tourist arrivals in the Maldives during the year 1972 to 2017, Figure 4 shows percentage share of tourism contribution trend in Maldives economy, while Table 1 provided the chronology of Maldives Tourism development viz-a-viz Tourism Master Plans.

The First Tourism Master Plan (1983-1992) employed sustainable tourism development approach and was primarily based on the inclusion of socioeconomic, cultural \& physical geography with proper zoning models and specific tourist centers. It ensured environmentally sustainable tourism by reducing island congestion, maintaining building heights compatible with natural vegetation and reef protection. The mandate of the Department of Tourism \& Foreign Investment was upgraded to a Ministry in 1988 for the purpose of institutional strengthening.

The outstanding issues for the attraction of private investments were addressed as part of the Second Tourism Master Plan 1995 (1996-2005), which encouraged Public-Private partnerships; and strengthened institutional effectiveness, human resource development, marketing, and promotion. The 2TMP encouraged the Spatial Development Policy to enable easy and fast expansion of industry for tourism infrastructure development. Promulgation of Tourism Law in 1998 provided incentives for selling shares of resorts to the public for longer lease periods. Introduction of Environmental Impact Assessment (EIA), proper solid waste management systems and compliance to ISO standards have

17 Tourism Year Books (2007-2017), Ministry of Tourism, Maldives. 
practically evolved sustainable tourism development in the Maldives.

The Third Tourism Master Plan (2007-2011) was developed by the Ministry of Tourism and Civil Aviation (MoTCA) focused on sustainable growth with the inclusion of public share investment, infrastructure development, environmental sustainability, branding Maldives tourist destination, and strengthening the legal framework \& institutional capacities. ${ }^{18}$

The Fourth Tourism Master Plan 4TMP (2013-2017) also focused on the inclusion of both public and private stakeholders and its strategies include ensuring enough supply of mediumrange resorts, resolving political issues, disaster management, mega Maldives tourist route expansion plans, effective and sustained future marketing strategic tools application. An o verall marketing budget of US $\$ 4,132,000$ was allocated in the year 2012 . This ultimately increased the tourist bed nights in hotels and resorts from 5.3 million to 6.4 million with an increasing rate of $4.7 \%$. The 4TMP projected to increase the tourist arrival to 2.5 million by the end of 2021. The effective execution of Maldives Tourism Plans has played a significant role in the uplift of the tourism sector of the Maldives economy. ${ }^{19}$

Just because of tourism, Maldives has graduated from one of the poorest countries in the 1970s with stunted growth to upper middle-income group. Now, it has the best social indicators in South Asia and highest income of US $\$ 15,665.50$ PPP rising from US. $\$ 100$ in $1970 \mathrm{~s}^{20}$.

\footnotetext{
18 Third Tourism Master Plan (200-2001).

${ }^{19}$ Fourth Tourism Master Plan (2013-2017)

${ }^{20}$ Maldives GDP per capita PPP, accessed on August 26, 2019, $: / /$ tradingeconomics.com/maldives/gdp-per-capita-ppp.
} 


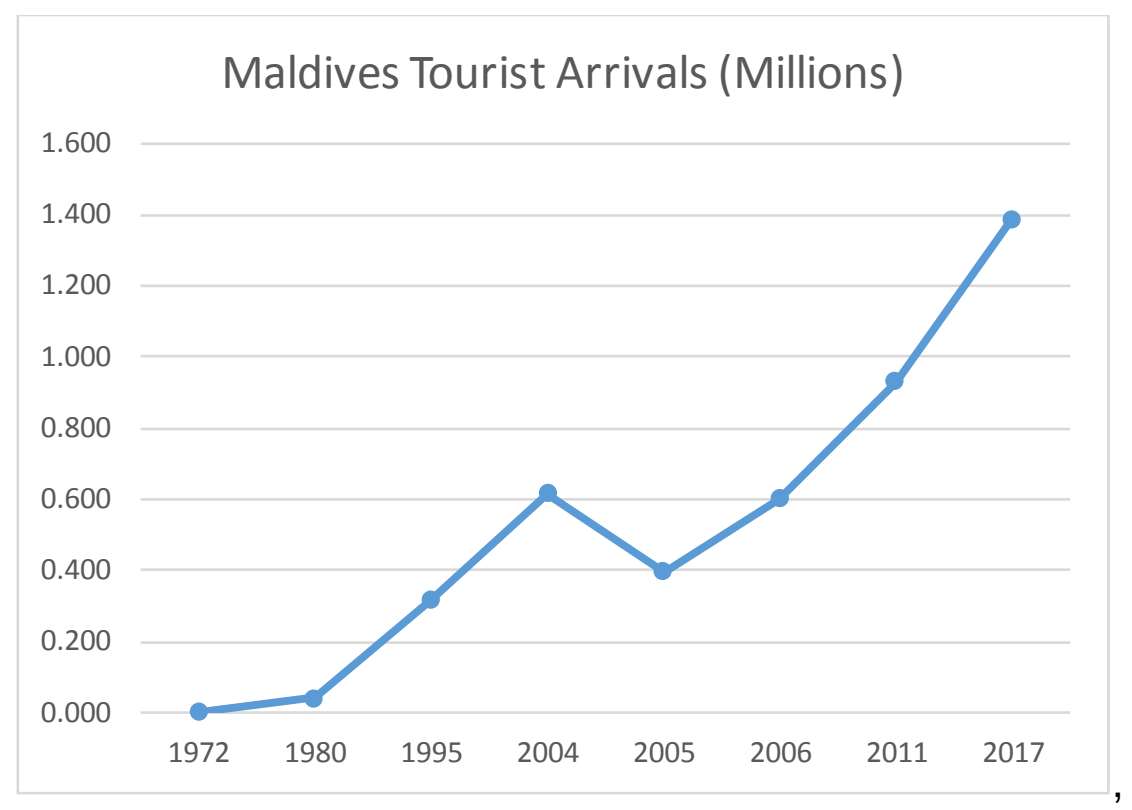

Figure 3: Trends of Tourist Arrivals in Maldives - 1972 to 2017. (Source: Tourism Year Books (2007-2017), Ministry of Tourism, Maldives)

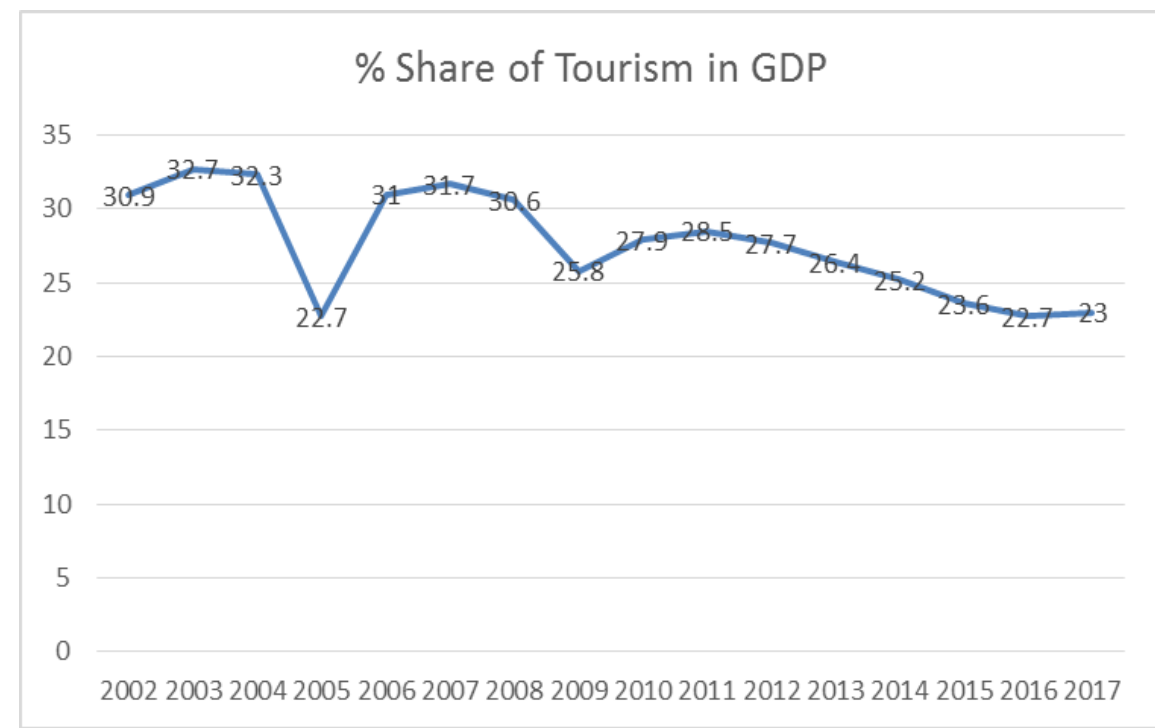

Figure 4: \% Share of Tourism contribution in the GDP (2002-2017) (Source: Tourism Year Books (2007-2017), Ministry of Tourism, Maldives) 
Table 1: Chronology Matrix of Maldives Tourism Development 1983-2017

\begin{tabular}{|c|c|c|c|c|c|}
\hline Timeline & $\begin{array}{c}\text { Tourism Products / Facilities } \\
\text { / Support Developed }\end{array}$ & $\begin{array}{c}\text { Policy, Legal, Institutional } \\
\text { Measure }\end{array}$ & $\begin{array}{c}\text { Incentives for } \\
\text { Private } \\
\text { investment }\end{array}$ & $\begin{array}{c}\text { Periodic Average } \\
\text { \%age share of } \\
\text { Tourism in GDP }\end{array}$ & $\begin{array}{l}\text { Tourist } \\
\text { Arrivals }\end{array}$ \\
\hline 1972-1982 & Tourism started & $\begin{array}{l}\text { No proper legal and } \\
\text { institutional measure }\end{array}$ & No incentive & Data not available & $\begin{array}{l}1097 \text { in } \\
1972\end{array}$ \\
\hline \begin{tabular}{|l|} 
1983-1992: \\
First Tourism \\
Master Plan
\end{tabular} & $\begin{array}{l}\text { b. Strategized Tourism } \\
\text { Zoning model with } 10,000 \text { beds } \\
\text { residence infrastructure per } \\
\text { tourist zone with tourist centers } \\
\text { c. Started proper tourism } \\
\text { with } 2 \text { island resorts and } 280 \\
\text { beds capacity } \\
\text { d. Was primarily based on } \\
\text { sea, sand and sun products } \\
\text { approach. } \\
\text { e. Cruise product started in } \\
\text { the } 1970 \text { s. }\end{array}$ & $\begin{array}{l}\text { a. The Department of } \\
\text { Tourism \& Foreign Investment } \\
\text { became a Ministry for Tourism } \\
\text { in } 1988 \\
\text { b. The Ministry of } \\
\text { Tourism took stringent actions } \\
\text { to avoid congestion on island, } \\
\text { construction of building heights } \\
\text { compatible with natural } \\
\text { vegetation and to ensure reef } \\
\text { protection. }\end{array}$ & & Data not available & $\begin{array}{l}42,000 \text { in } \\
1980 \\
315,000 \text { in } \\
1995 \\
650 \%\end{array}$ \\
\hline $\begin{array}{l}\text { 1996-2005: } \\
\text { Second } \\
\text { Tourism } \\
\text { Master Plan }\end{array}$ & 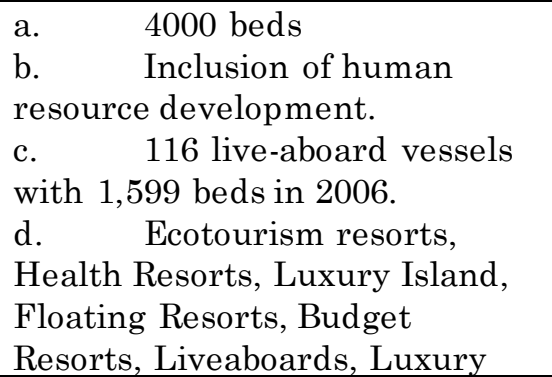 & $\begin{array}{l}\text { a. Maldives } \\
\text { Promotion Board (MPTD) was } \\
\text { formed in } 1998 \\
\text { b. The Maldives Tourism } \\
\text { Act (Law No. 2/99) was enacted } \\
\text { in 1999. } \\
\text { c. Spatial Development } \\
\text { Policy developed a transparent } \\
\text { and formal framework for }\end{array}$ & $\begin{array}{l}\text { a. Tourism } \\
\text { Law } 1998 \text { provided } \\
\text { incentives for } \\
\text { selling shares of } \\
\text { resorts to the } \\
\text { public for a longer } \\
\text { lease span. } \\
\text { b. Exemption } \\
\text { of import duty on }\end{array}$ & $29.65 \%$ & $\begin{array}{l}315,000 \text { in } \\
1995 \\
395,320 \text { in } \\
2005 \\
25 \%\end{array}$ \\
\hline
\end{tabular}




\begin{tabular}{|c|c|c|c|c|c|}
\hline Timeline & $\begin{array}{c}\text { Tourism Products / Facilities } \\
\text { / Support Developed }\end{array}$ & $\begin{array}{c}\text { Policy, Legal, Institutional } \\
\text { Measure }\end{array}$ & $\begin{array}{c}\text { Incentives for } \\
\text { Private } \\
\text { investment }\end{array}$ & $\begin{array}{c}\text { Periodic Average } \\
\text { \%age share of } \\
\text { Tourism in GDP }\end{array}$ & $\begin{array}{l}\text { Tourist } \\
\text { Arrivals }\end{array}$ \\
\hline & $\begin{array}{l}\text { Yachts, and Training Resorts } \\
\text { were identified for future } \\
\text { infrastructure development. }\end{array}$ & $\begin{array}{l}\text { infrastructure } \\
\text { financing by enhancing local } \\
\text { investments } \\
\text { d. Maldives } \\
\text { Department Tourism } \\
\text { (MTDC) formed in } 2006 \text { to } \\
\text { provide avenues for investment } \\
\text { in tourism. } \\
\text { e. Facilitation to Public- } \\
\text { Private Sector investments. } \\
\text { f. Tourism Emergency } \\
\text { Operations Centre (TEOC) was } \\
\text { proposed under the Disaster } \\
\text { Management Strategy and Plan } \\
\text { in 2005. } \\
\text { g. Ensured development of } \\
\text { Disaster Preparedness Plans } \\
\text { (DPP) by each resort (2005 } \\
\text { onward). } \\
\text { h. Provision } \\
\text { institutional support for } \\
\text { products of diving and travel } \\
\text { agencies. } \\
\text { i. Long leases on state- } \\
\text { owned islands and land ear- }\end{array}$ & $\begin{array}{l}\text { construction } \\
\text { materials. } \\
\text { c. Duty } \\
\text { exemption on } \\
\text { capital goods for } \\
\text { resort development. }\end{array}$ & & \\
\hline
\end{tabular}




\begin{tabular}{|c|c|c|c|c|c|}
\hline Timeline & $\begin{array}{l}\text { Tourism Products / Facilities } \\
\text { / Support Developed }\end{array}$ & $\begin{array}{c}\text { Policy, Legal, Institutional } \\
\text { Measure }\end{array}$ & $\begin{array}{l}\text { Incentives for } \\
\text { Private } \\
\text { investment } \\
\end{array}$ & $\begin{array}{c}\text { Periodic Average } \\
\text { \%age share of } \\
\text { Tourism in GDP } \\
\end{array}$ & $\begin{array}{l}\text { Tourist } \\
\text { Arrivals }\end{array}$ \\
\hline & & $\begin{array}{l}\text { marked for } \\
\text { development. } \\
\text { j. Provision of Joint- } \\
\text { venture agreements with the } \\
\text { Government for integrated } \\
\text { developments and large-scale } \\
\text { housing projects. (PPP) }\end{array}$ & & & \\
\hline $\begin{array}{l}\text { Third } \\
\text { Tourism } \\
\text { Master Plan } \\
(2007-2011)\end{array}$ & $\begin{array}{l}\text { a. } 89 \text { islands were } \\
\text { developed for tourist resorts } \\
(2006) \text {. } \\
\text { b. Relaxation \&Honeymoon } \\
\text { facilities. } \\
\text { c. Underwater Diving, } \\
\text { Cruising, 'liveaboards', diving } \\
\text { safaris. } \\
\text { d. Others - health \& spa. } \\
\text { e. Marinas on Dhonakulhi } \\
\text { Island with the berthing of about } \\
25 \text { yachts and } 50 \text { guests capacity. }\end{array}$ & $\begin{array}{l}\text { a. Developed an exclusive } \\
\text { legal analysis framework under } \\
\text { the Tourism Act. } \\
\text { b. The Maldives Tourism } \\
\text { Act provided guidelines for } \\
\text { leasing of islands for } \\
\text { infrastructure development by } \\
\text { investors. } \\
\text { C. Article } 8 \text { stated that } \\
\text { islands and land must be leased } \\
\text { for tourist resort development } \\
\text { for a maximum period of } 25 \\
\text { years. }\end{array}$ & $\begin{array}{l}\text { a. Provision } \\
\text { of long leases up to } \\
99 \text { years for } \\
\text { housing } \\
\text { developments. }\end{array}$ & $28.78 \%$ & $\begin{array}{l}678,889 \text { in } \\
2007 \\
931,333 \text { in } \\
2011 \\
\\
37.1 \%\end{array}$ \\
\hline $\begin{array}{l}\text { Fourth } \\
\text { Master } \\
\text { Tourism Plan } \\
\end{array}$ & $\begin{array}{l}\text { a. } \quad \text { Fly-surfing, Luxury } \\
\text { Safari boats, Cruise Operations. } \\
\text { b. } \quad \text { 4 Airports } \\
\end{array}$ & $\begin{array}{l}\text { a. Maldives Marketing \& } \\
\text { Public Relations Corporation } \\
(\text { MMPRC) established in March }\end{array}$ & & $24.18 \%$ & $\begin{array}{l}1,125,202 \\
\text { in } 2013\end{array}$ \\
\hline
\end{tabular}




\begin{tabular}{|c|c|c|c|c|c|}
\hline Timeline & $\begin{array}{c}\text { Tourism Products / Facilities } \\
\text { / Support Developed }\end{array}$ & $\begin{array}{c}\text { Policy, Legal, Institutional } \\
\text { Measure }\end{array}$ & $\begin{array}{c}\text { Incentives for } \\
\text { Private } \\
\text { investment }\end{array}$ & $\begin{array}{c}\text { Periodic Average } \\
\text { \%age share of } \\
\text { Tourism in GDP }\end{array}$ & $\begin{array}{l}\text { Tourist } \\
\text { Arrivals }\end{array}$ \\
\hline $\begin{array}{l}\text { 4MTP (2013- } \\
2017)\end{array}$ & operationalized & $\begin{array}{l}2010 \text { with the inclusion of } \\
\text { fisheries, agriculture, and } \\
\text { public education along with the } \\
\text { tourism sector. } \\
\text { b. Effective and sustained } \\
\text { future marketing strategic tools } \\
\text { application in order to attract } \\
\text { private investors. } \\
\text { c. In } 2012 \text {, an overall } \\
\text { Maldives marketing budget of } \\
\text { US } \$ 4,132,000 \text { was allocated }\end{array}$ & & & $\begin{array}{l}1,389,542 \\
\text { in } 2017 \\
23.4 \% \\
\text { increase }\end{array}$ \\
\hline
\end{tabular}




\section{The Case of Pakistan's Maritime Tourism -Analysing Pakistan's Potential}

While discussing the potential of maritime tourism in Pakistan as direct economic activities; Pakistan has miles of sandy beaches, coastal highways which connect coastal areas to other parts of country, Karachi, one of the mega cities of the world with middle class hungry for beach activities and warm waters. The Balochistan coastline possesses muddy cliffs with rocky land and number of sandy beaches including Somiani, Gwadar, Pasni, Ormara, and Astola Island. Around 3,000 hectares of Mangroves forests covers the whole province ${ }^{2122}$. Miani Hor, Jiwani, Pasni, and Hingol are referred to as most vital sites for the migratory birds including waterfowls by ornithologists ${ }^{23}$. The Hingol National Park \& Buzi Makola, Wildlife Sanctuary ${ }^{24}$ are marked as Protected Areas of the region. Astola Island, Miani Hor, Jiwani and Or mara are marked as Ramsar Sites ${ }^{25}$. Architectural resources include tombs, forts, mosques, graves, and other historical monuments in Balochistan (BCS, 2000) ${ }^{26}$. This rich biological diversity and historic and cultural diversity provides great opportunities for ecotourism development.

21 Endangered Mangroves forest of Pakistan, Technology Times.PK, September 15, 2017, https://www.technology times.pk/endangered-mangrove-forest-pakistan/.

22 Mirza, M. I., Hasan, M. Z., Akhtar, S., Ali, J., \& Sanjrani, M. A., "Remote sensing survey of mangrove forest along the coast of Balochistan," Marine science of the Arabian Sea, (1988): 339-348.

${ }^{23}$ Ahmed, M.F., Ghalib, S.A. and Hasnain, S.A. (1991) The Waterflow of Makran Coast. In Proceedings of three days National Conference on Problems and Resources of Makran Coast and Plan of Action for its Development. Karachi Zoological Survey Department.

24 What is Wildlife Sanctuary, Performing Animal Welfare Society, Accessed on August 26, 2019, https://www.pawsweb.org/what_is_a_wildlife_sanctuary.html.

25 Ramsar Convention Bureau, Pakistan designated eight new Ramsar Sites. (2001), Accessed on June 12, 2019, http://www.ramsar.org/wn/w.n.pakistan_eightnew.html.

26 BCS - Balochistan Conservation Strategy, The Strategy prepared by the Planning and Development Department, Government of Balochistan, (2000), Accessed on June 12, 2019, http://www.bcs.iucnp.org. 
Sindh's potential coastal tourism resources include rich biodiversity, protected areas, serene sandy beaches, mangrove forests, and internationally renowned Indus Delta. Mangroves provide ideal conditions for marine \& terrestrial wildlife. Like other countries, ecotourism can play a significant role in ensuring the conservation of natural beauty spread over hundreds of miles of sandy beaches and economic growth of Pakistan ${ }^{27}$.

Ideal temperature for tourism in coastal areas is from October to March especially for surfing and snorkelling activities. The 6 th largest Mangroves in the world in the Indus Delta have great ecotourism attraction for tourists across the globe. There are a number of activities, which can be linked with the Lagoons, Diving sites, Dolphins and Crocodiles watching and other attractions in Hingol National Park which includes: Wildlife and Bird watching, Turtle watching, Mud volcanoes and many more undiscovered areas so far.

A tourist destination can bring important revenues to the state budget in the form of taxes and fee paid by companies, who operate around such attractions. This provides a source of income for local communities and creates an interesting shopping experience for tourists. Another very important aspect of Maritime tourism is Eco-tourism, which is defined as "Responsible travel to natural areas, which conserves the environment and improves the welfare of local people". The purpose behind the Eco-tourism is to develop awareness among the general public to build environmental and cultural awareness and respect. It economically benefits the local communities and provides direct financial benefits for conservation.

Figure 5 and Table 2 provide information on identified to urism sites for different kinds of maritime tourism activities and products, which can be introduced by applying the cluster development approach for nearby sites.

${ }^{27}$ Himayatullah Khan, "Demand for eco-tourism: Estimating recreational benefits from the Margalla hills national park in northern Pakistan", (2004). 


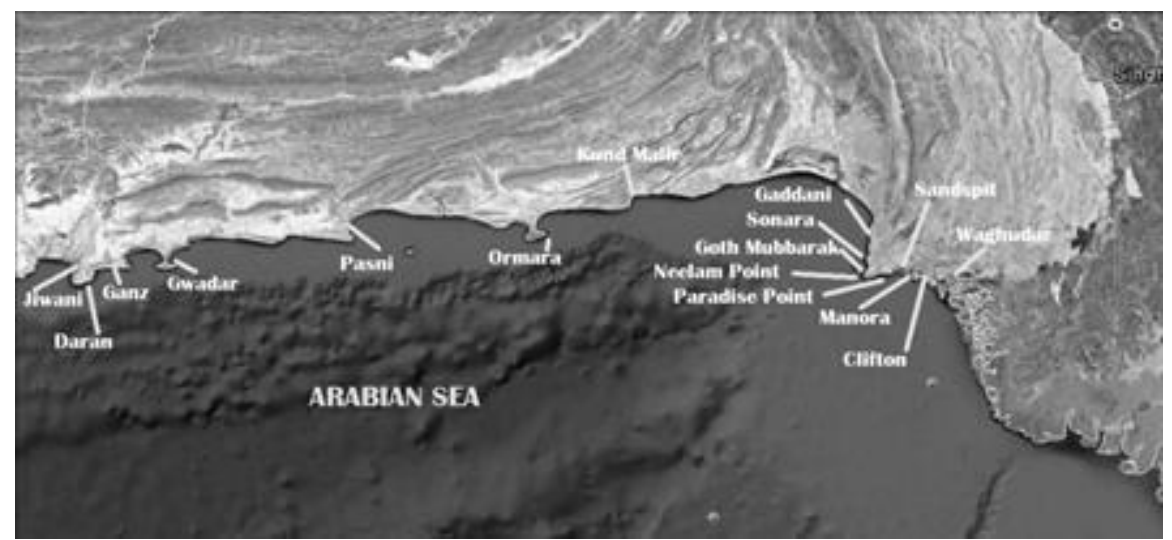

Figure 5: Map showing Coastal Areas of Pakistan for the Potential of Maritime Tourism Development

Table 2: Potential Sites and Products for Maritime Tourism in Pakistan

\begin{tabular}{|c|c|c|c|}
\hline $\begin{array}{c}\mathrm{S} \\
\text { No }\end{array}$ & $\begin{array}{l}\text { Proposed } \\
\text { Locations }\end{array}$ & Tourism Products/Activities & $\begin{array}{c}\text { Type of Tourism } \\
\text { Product }\end{array}$ \\
\hline 1. & $\begin{array}{l}\text { Indus River } \\
\text { estuary near } \\
\text { Keti Bandar, } \\
\text { Sindh. }\end{array}$ & $\begin{array}{l}\text { Dolphin watching, Backwater } \\
\text { Tourism by introducing } \\
\text { houseboats, cruise activities, } \\
\text { parking bays, boarding points. }\end{array}$ & $\begin{array}{l}\text { Recreational \& } \\
\text { Eco-tourism }\end{array}$ \\
\hline 2. & Karachi City & $\begin{array}{c}\text { Shopping centers, restaurants, } \\
\text { Mazar-e-Quaid, Residence of } \\
\text { Quaid-e-Azam }\end{array}$ & $\begin{array}{c}\text { Cultural, } \\
\text { Religious \& } \\
\text { Recreational } \\
\text { Tourism }\end{array}$ \\
\hline 3. & $\begin{array}{c}\text { Seaview } \\
\text { Beach Karachi }\end{array}$ & $\begin{array}{l}\text { Water sports activities, } \\
\text { Restaurant Cruises }\end{array}$ & $\begin{array}{c}\text { Adventure \& } \\
\text { Recreational } \\
\text { Tourism }\end{array}$ \\
\hline 4. & $\begin{array}{l}\text { Hawksbay/ } \\
\text { Sandspit } \\
\text { Beach, } \\
\text { Karachi }\end{array}$ & $\begin{array}{l}\text { Water sports activities, Green } \\
\text { Turtle Watching,_Guest houses. }\end{array}$ & $\begin{array}{c}\text { Adventure, } \\
\text { Recreational/ Eco- } \\
\text { tourism }\end{array}$ \\
\hline 5. & $\begin{array}{c}\text { Manora Island } \\
\text { Beach }\end{array}$ & $\begin{array}{l}\text { Famous Picnic Spot with Sandy } \\
\text { Beach and the attraction of } 28 \mathrm{~m} \\
\text { Lighthouse, water sports } \\
\text { activities, Guest houses. }\end{array}$ & $\begin{array}{l}\text { Recreational } \\
\text { Tourism }\end{array}$ \\
\hline 6. & $\begin{array}{l}\text { Beach near } \\
\text { Mubarak } \\
\text { village }\end{array}$ & $\begin{array}{c}\text { Water sports activities, Guest } \\
\text { Houses, Model village. }\end{array}$ & $\begin{array}{l}\text { Adventure, } \\
\text { Recreational } \\
\text { Tourism }\end{array}$ \\
\hline
\end{tabular}




\begin{tabular}{|c|c|c|c|}
\hline $\begin{array}{c}\text { S } \\
\text { No }\end{array}$ & $\begin{array}{l}\text { Proposed } \\
\text { Locations }\end{array}$ & Tourism Products/Activities & $\begin{array}{c}\text { Type of Tourism } \\
\text { Product }\end{array}$ \\
\hline 7. & Churna Island & Scuba diving, Live aboard boats. & $\begin{array}{c}\text { Adventure, } \\
\text { Recreational, Eco- } \\
\text { tourism }\end{array}$ \\
\hline 8. & $\begin{array}{c}\text { Gadani, } \\
\text { Lasbela } \\
\text { district } \\
\text { Balochistan } \\
\end{array}$ & $\begin{array}{l}\text { Gadani ship-breaking yard, } \\
\text { Paradise Point, Fish Harbour, } \\
\text { Beach activities,_Guest Houses. }\end{array}$ & \begin{tabular}{|c|} 
Recreational/ \\
Cultural/ \\
Educational \\
Tourism \\
\end{tabular} \\
\hline 9. & Somiani & $\begin{array}{c}\text { Somiani Spaceport, } \\
\text { Famous Beach for Recreation } \\
\text { and variety of Fish, Guest } \\
\text { Houses. }\end{array}$ & $\begin{array}{l}\text { Recreational, Eco- } \\
\text { tourism }\end{array}$ \\
\hline 10. & \begin{tabular}{|c|} 
Chandar Gup \\
Mud Volcano \\
site, Hingol \\
National Park, \\
Balochistan
\end{tabular} & $\begin{array}{c}\text { Hindus worship site, scenic } \\
\text { beauty - Hot Air Balloon and } \\
\text { other hospitality services }\end{array}$ & $\begin{array}{l}\text { Religious/ Eco- } \\
\text { tourism }\end{array}$ \\
\hline 11. & \begin{tabular}{|c|} 
Hingol \\
National Park, \\
Balochistan \\
(including \\
nearby Jhal \\
Jao) \\
\end{tabular} & $\begin{array}{l}\text { Camping sites, hiking trails, } \\
\text { Ibex, Urial, Chinkara watching } \\
\text { spots }\end{array}$ & $\begin{array}{l}\text { Recreational, Eco- } \\
\text { tourism }\end{array}$ \\
\hline 12. & $\begin{array}{l}\text { Hingol River } \\
\text { estuary area, } \\
\text { Balochistan }\end{array}$ & $\begin{array}{l}\text { Backwater tourism by } \\
\text { introducing houseboats, cruise } \\
\text { activities, parking bays, } \\
\text { boarding points. Hot air } \\
\text { ballooning joy rides, Crocodile } \\
\text { watching spots,_Guest Houses. }\end{array}$ & $\begin{array}{l}\text { Recreational \& } \\
\text { Eco-tourism }\end{array}$ \\
\hline 13. & \begin{tabular}{|c|} 
Nani Mandir, \\
Hinglaj town, \\
Lasbela \\
\end{tabular} & $\begin{array}{l}\text { Hindu temple, historical site, } \\
\text { Hot Air Balloon,_Guest Houses. }\end{array}$ & $\begin{array}{c}\text { Religious / } \\
\text { Cultural Tourism }\end{array}$ \\
\hline 14. & \begin{tabular}{|c|} 
Kund Malir \\
(Sandy beach), \\
including \\
Ormara Area \\
(Ramsar \\
Site) 28 \\
\end{tabular} & $\begin{array}{c}\text { Leisure activities, Water Sports, } \\
\text { Scuba Diving, Parasailing, } \\
\text { Hotels, Restaurants, Model } \\
\text { Tourist Village. }\end{array}$ & $\begin{array}{l}\text { Recreational } \\
\text { Tourism / } \\
\text { Eco-tourism }\end{array}$ \\
\hline
\end{tabular}

28 "A Ramsar site is a wetland site designated to be of international importance under the Ramsar Convention. The Convention on Wetlands, known as the Ramsar 


\begin{tabular}{|c|c|c|c|}
\hline $\begin{array}{c}\text { S } \\
\text { No }\end{array}$ & $\begin{array}{c}\text { Proposed } \\
\text { Locations }\end{array}$ & Tourism Products/Activities & $\begin{array}{c}\text { Type of Tourism } \\
\text { Product }\end{array}$ \\
\hline 15. & $\begin{array}{c}\text { Princess of } \\
\text { Hope (near } \\
\text { Buzipass) }\end{array}$ & $\begin{array}{c}\text { Hot Air Balloon - Fascinating } \\
\text { Natural Rock formations, } \\
\text { Paragliding. }\end{array}$ & Eco-tourism \\
\hline 16. & Astola Island & $\begin{array}{c}\text { Scuba diving, Green turtles and } \\
\text { Birds watching sites,_Guest } \\
\text { Houses. }\end{array}$ & $\begin{array}{c}\text { Adventure, Eco- } \\
\text { tourism }\end{array}$ \\
\hline 17. & $\begin{array}{c}\text { Gwadar, } \\
\text { Balochistan }\end{array}$ & $\begin{array}{c}\text { Hot Air Balloon, Paragliding, } \\
\text { Parasailing, and Historical Fort. }\end{array}$ & $\begin{array}{c}\text { Recreational / } \\
\text { Cultural Tourism, } \\
\text { Eco-tourism }\end{array}$ \\
\hline 18. & Jiwani & $\begin{array}{c}\text { A historical site that includes } \\
\text { historical airport used in World } \\
\text { War II and Victoria Hut with a } \\
\text { scenic viewpoint, Guest Houses. }\end{array}$ & $\begin{array}{c}\text { Cultural Tourism, } \\
\text { Eco-tourism }\end{array}$ \\
\hline 19. & $\begin{array}{c}\text { Makran Coast, } \\
\text { Balochistan }\end{array}$ & $\begin{array}{c}\text { Parailing, Surfing, Sailing, } \\
\text { speed boating/water scooter } \\
\text { riding/Banana boat riding/sea } \\
\text { kayaking, etc all along the } \\
\text { coastal highway. }\end{array}$ & $\begin{array}{c}\text { Recreational / } \\
\text { Adventure } \\
\text { Tourism }\end{array}$ \\
\hline
\end{tabular}

\section{Challenges to Maritime Tourism in Pakistan}

Historically, Karachi had a lot of Maritime tourism until the 1970s in comparison to contemporary times. There were dozens of "Bunder" sailing boats playing in the Harbour, where families as well as foreigners used to spend their evenings. The Ke mari Boat Basin and Clifton Beaches were unpolluted and clean, where the general public were frequent visitors for picnics and swimming. There were numerous huts on Sandspit, Hawksbay and Paradise point. All this is history and there are no bunder boats or weekly regattas, majority of huts are dilapidated with few wellmaintained beach properties belonging to the elite or large organizations only.

The major challenges have been faced by Pakistan in maritime tourism development include lack of stakeholders' collaboration, strategic management \& planning, biodiversity loss, political

*Convention, is an intergovernmental environmental treaty established in 1971 by

UNESCO, which came into force in 1975." 
conflicts, and national level interest for the coastal tourism development ${ }^{29}$. During consultative workshop on maritime tourism by NIMA, it was highlighted that there are certain impediments in Pakistan's maritime tourism which have been confronted including: Lack of infrastructure and facilities for domestic tourists, training facilities for large number of hospitality staff, no infrastructure development for roadside restaurants and tourist facilities \& poor hygiene standards of present facilities ,difficulties in land acquisition for the construction of motels, poor visitors' orientation, no arrangement for solid waste disposal and lack of awareness among local communities about tourism business, NOC required for foreigners to visit coastal areas in Balochistan, no Provincial Government facilitation for tourism, no land or areas marked for tourism, no decent public transportation for middle class families, conflict between Federal and Provincial Governments, no enabling environment, non-existence of fiscal incentives, poor marketing in the tourism sector for private investors, costly coastal infrastructure development as well as long lead time, lack of potable water and desalination plants, no co-ordination between various government or security agencies for the facilitation of maritime tourism.

Security agencies at Ormara, Pasni prohibit the locals to visit coastal areas and are marked as No-Go Areas for recreational and water sports activities. The equipment and products for water sports activities is not manufactured in Pakistan and are mainly imported from different parts of the world. The prices of this imported equipment for water sports activities are very high. The entrepreneurs like Scuba Diving Clubs, snorkelling service providers have been facing severe challenges of acquiring NOC and security issues in the maritime tourism sector. In the month of monsoon season, District Authorities under Section 144 prohibit the local tourists from going out to sea for Surfing, Scuba Diving etc. despite the waves being ideal for these sports.

${ }^{29}$ Ullah, and Haq. "Coastal Tourism \& CPEC: Opportunities and Challenges in Pakistan". 


\section{An Overview of National Policies and their relevance Maritime Tourism}

The National Tourism Policy-1990 was quite an attractive document as it accorded industry status to the tourism sector and guaranteed same industrial benefits, monetary incentives, concessions and treatments to all tourism-related facilities with an additional incentive of an 8-year tax holiday for the tourism projects launched during July 1990 to June 1995. The geographic scope of concessionary loan financing was also extended to all over Pakistan including the coastal areas (except Karachi cosmopolitan jurisdiction), which were earlier limited to northern areas only. The charter flights, tourist helicopters/small planes were also allowed for private sector operations. Provisions were made for 72 hour transit to multiple entry visas for 4-5 years' work permits. Leasing of government-owned facilities was allowed for private sector operations. Under Part VII Clause 45, import of special equipment for adventure tourism activities like water sports, hang gliding, trekking, mountaineering, angling, golf, indoor sports equipment, power boats, water rafts, canoes, water and snow skilling equipment were allowed free of custom duty and sales tax in order to keep the cost of operation low and enable active engagement of private sector at large. These incentives were critically important for materializing coastal tourism potential over a period of time. However, $5 \%$ customs duty was imposed in 2007 on this kind of special equipment during the revision of Pakistan National Tourism Policy, which was a discouraging factor considering various challenges to the maritime tourism segment.

In a parallel development under Section-VI of National Maritime Policy 2002, the importance of maritime touris m, water sports, and infrastructure development along the coast was also emphasized by the Federal Government. Under the same section, the National Maritime Policy 2002 augmented the agenda of National Tourism Policy 1990 by justifying the need to evolve long term provincial policies for the promotion of tourism and water sports by the Ministry of Sports, Culture, Tourism and Youth Affairs in consultation with the provinces of Sindh and Balochistan. However, the federal context of the tourism segment was changed particularly after the 18th Amendment in the Constitution of Pakistan after that tourism became purely a 
provincial subject with no clarity on the responsible institution for maritime tourism and all other incentives as were guaranteed vide National Tourism Policy 1990. Due to these bottlenecks and for some other reasons such as prevailing security situation after 9/11, things could not move in the right direction to put into practice any improved version of policies in Balochistan and Sindh to address outstanding issues and harness the true potential of maritime tourism in Pakistan.

\section{Latest Federal Developments}

In order to revive tourism sector in Pakistan, the Federal Cabinet under case no.123/06/2019 revised the Visa Policy on 31.01.2019 and granted 3 months validity visit/tourist and double stay entries to foreigners of 190 countries. 50 countries were also granted Visa-on-arrival for individual tourist or group tourists $(\mathrm{PTDC}, 2019)^{30}$. Indeed, it is a positive step in the promotion of the tourism sector in Pakistan. On 12th March 2019, the Federal Government devised the National Tourism Coordination Board (NTCB) in order to facilitate tourism in coordination and consultation with all concerned provinces. It's also a great step towards tourism development and it is hoped that NTCB will be able to produce tangible outcomes particularly by realizing the true potential of maritime tourism in Pakistan. This board comprises Chairman Board of Investment (BOI), Secretary Inter provincial Coordination, Joint Secretaries of Civil Aviation Authority (CAA), Foreign Office, Ministry of Interior, Ministry of Information, Secretaries of provincial tourism departments, representatives of private sector trade bodies such as PATO, TAAP (Travel Agents Association of Pakistan) and PHA (Parks and Horticulture Authority). Initially, there were 9 working groups created in NTCB by Prime Minister of Pakistan. Whereas, maritime tourism component was still missing ${ }^{31}$. On 4th April 2019, a need for the creation of maritime tourism was rationalized as one of the outcomes of stakeholder's consultative seminar on

30 Revision of Visa Regime (2019). Government of Pakistan, Ministry of Interior.

31 Government of Pakistan (2019). Constitution of National Tourism Coordination Board (NTCB). Notification F.No.10-7/2019-Org-III(i) (2019) dated 12.03.2019, published in Gazette of Pakistan, Cabinet Secretariat (Cabinet Division). 
Potential of Maritime Tourism Development in Pakistan organized by National Institute of Maritime Affairs (NIMA) at Karachi. The TORs for the same Working Group on Maritime Tourism is under the approval process by the Federal Government of Pakistan.

The NTCB has the mandate to coordinate with different national and international Private investors to boost this very sector of Pakistan economy. It will also focus on the exclusive marketing and promotion strategies along with the provision of technical assistance to the provinces in order to uplift the tourism sector in the Pakistan economy ${ }^{32}$. Apart from that, Sindh Tourism Policy is awaiting approval since 2014. The policy though covers some aspects of coastal tourism. However, it is needed to be reviewed before approval/implementation.

\section{Findings and Conclusion}

Pakistan is blessed with more than $1000 \mathrm{~km}$ serene coastline of sandy beaches, which has huge potential for maritime tourism. However, it still ranks very low i.e., 125 in terms of world tourism income. Pakistan is facing many challenges in tourism sector of economy. The gravity of issues is more severe in case of coastal tourism. The National Tourism Policy-1990 is no more effective after the 18th amendment in the constitution, where the role of provinces i.e., Sindh \& Balochistan in order to materialize infrastructure development and allied facilities along the coast. Also, Sindh Tourism Policy has been waiting for approval since 2014. Although, it covers some maritime tourism sector in the draft, which also needs to revisit it prior to its requirement. It is also the fact that Pakistan has been actively engaged in a war on terrorism. Due to which, the tourism sector remained disturbed over the last two decades. There are many tourist attractions along the Balochistan coast which are affected due to security and mobility issues of foreign tourists.

It is generally opined that maritime tourism would be quite challenging or near to impossible in Pakistan, given the various

32 "PM Imran Khan Approves National Tourism Coordination Board", Pakistan Today, March 13, 2019, https://www.pakistantoday.com.pk/2019/03/13/pm-imranapproves-national-tourism-coordination-board/ 
reasons of security, safety, confusion in the ownership of coastal areas, NOC requirement, infrastructure development, climatic conditions, policy and governance issues, confused status of incentives to private sector after 18th amendment in the constitution of Pakistan, absence of proper planning mechanism and clear road map, low level of importance prior to devise marketing strategy, poor coordination among various departments and federal vs provincial governments etc.

But the true potential has a tale in itself, which can be a success story like Maldives where tourism was considered impossible. There is a need to understand the measures and overall governance behind the success stories. Various countries such as Maldives, Singapore, Thailand and Kerala state in India etc. have focused agenda on maritime tourism and have evolved good governance practices thus generating substantial revenues from it.

The early phase of tourism in Kerala was quite low which, now has grown to an impressive level of earnings over US $\$ 5$ billion per annum. It is pertinent to notice that it has an upward and exponential grow th trends with reported figures of foreign tourist arrivals more than 1 million and domestic tourists around 15 million in the year 2017. The success story of Kerala was achieved due to the dynamic, effective and continual mode of policy processes and instruments, which have boosted up this sector of maritime economy. Pakistan's coast, particularly at Keti Bunder in Sindh, can also be explored to replicate the good experiences of backwater tourism product of Kerala.

Maldives's economy primarily relies on maritime tourism with approximate $28.78 \%$ of its contribution towards national GDP (the average figures during the implementation of Third Tourism Master Plan, 2007 - 2011,). Tourism in Maldives started with only 280 beds capacity on 2 resorts with 1097 tourists in 1972. Maldives has achieved global tourism success through its national determination, strategic planning and its effective execution with good governance norms and product-based approach evolved from 1st Master Plan (1983-1992) to 4th Master Plan (2013-2017). The early phase Master Plans were of 10 years-time span which, are now reduced up-to 5 years. This reduction in review period of Master Plans is seemed rationale considering the increased manifold operations of tourism in Maldives and to address various 
requirements from frequent visits of tourists which is critically important in the context of consumer economy and customer satisfaction.

To conclude, experiences of Maldives on maritime tourism activities may be equally replicated on many places of Pakistani coast. The establishment of National Tourism Coordination Board (NTCB) in March 2019 with different working groups including Maritime Tourism working group is a good step for the revival of tourism in Pakistan. The factors behind the success stories of Maldives and Kerala state in India can act as guidance for taking initiatives on the proposed potential coastal tourism sites in order to uplift the maritime tourism sector in Pakistan. With the effective implementation of appropriate actions for the facilitation of coastal tourism, Pakistan Maritime tourism economy will reach to greater heights.

\section{Recommendations - The Way Forward}

In order to promote maritime tourism in Pakistan and to get the maximum potential from this sector of the economy, the following recommendations are devised by analyzing the success factors behind global experiences and shortcomings of Pakistan's tourism sector viz-a-viz potential and challenges.

(1) A comprehensive Maritime Tourism Strategic Plan and Road Map needs to be developed by National Tourism Coordination Board (NTCB) at federal level, in consultation with provincial governments of Sindh and Balochistan as well as all relevant stakeholders. Maldives also developed Tourism Master Plans on periodic basis, which played an instrumental role in their success story.

Prior to finalizing Maritime Tourism Strategic Plan based on the principles of sustainable tourism development, there is a need to carry out tourism site specific studies and land-use plan which is important for development of infrastructure, facilities and products such as motels, guest houses, tourism villages, etc., including recreational watersports/diving/snorkelling sites. Potential tourism sites and products in Table 2 under section 4.1 of this paper may be used for detailed analysis/feasibility and declare them 
accordingly (for motels, guest houses, tourism villages, recreational water sport/diving/snorkelling sites, eco-tourism etc.).

(3) Since National Tourism Policy-1990 is no more effective after the $18^{\text {th }}$ Amendment in the Constitution of Pakistan, there is an utmost requirement to revisit existing Policies, Legal and Institutional Framework by identifying the gaps in National/Provincial regulations, laws and policies which hamper the develop ment of maritime tourism.

(4) For an effective and vibrant mechanism, establish a Maritime Tourism Agency / Board as a Regulatory and Coordination Body among various stakeholders, and prepare its rules and regulations for one-window operations.

There is a need to establish a Contingency Response Cell to tackle any emergency / or crisis situation to the tourists in the coastal areas, like in State of Kerala. This cell needs to be adequately equipped with staff and infrastructure.

(6) In order to develop and promote coastal tourism in Pakistan, the Federal Government of Pakistan should take up initiatives similar to Kerala Tourism development with primary focus on infrastructure development including water-supply system, road accessibility, electricity \& streetlights and efficient waste management system.

(7) There is a need to devise an effective marketing strategy and a Task Force for it, with proper budget allocation for small and medium investors for motels, guest houses, tourism villages, water sports activities, beach games, etc.

An entrepreneurship development programme needs to be developed to enable Local Level Entrepreneurs (LLE) for the uplift of community-based tourism.

(9) Duties should be exempted on the import of equipment related to water sports activities and incentives should be provided to attract the investment in this very important sector of Pakistan's blue economy. 
(10) In order to attract foreign tourists and quality assurance, the hotel and hospitality management capacity needs to be enhanced through specialized programme and short courses. It will also help in utilization of local human resource capital in a best way and alleviation of poverty by improving their livelihood. To serve the purpose at large, a capacity mapping followed by Capacity building of requisite manpower and relevant stakeholders is strongly recommended.

(11) There is a need to develop a model Live-aboard Safari boats based on traditional designs to uplift livelihood of local communities.

(12) There is a need to develop at-least one or two model tourism site (s). One site can be developed at Kund Malir area in Balochistan and the other at Keti Bandar in Sindh. Keti Bandar area can be developed on the model of Kerala. While, Hingol River may be used for water supply purpose at Kund Malir area in initial phase thus the cost of sea water utilization may be managed in initial phase.

(13) Identify job opportunities for poverty alleviation of coastal communities.

(14) Preserve and promote cultural heritage of coastal community by establishment of culture centers.

(15) Suggest measures to prevent pollution and protecting the environment, particularly important for the major issue of plastic waste. A Coastal Areas Pollution Control Board may be constituted under Ministry of Maritime Affairs (MoMA).

(16) Identify feasibility for high-end tourist resorts under CPEC.

(17) Take measures to de-conflict various Government Security Agencies and allied departments.

(18) Develop supplementary facilities which would aid in promoting maritime tourism such as roads, fuel stations, mobile/internet coverage, service stations along coastal highways etc. 